\title{
O IMPACTO DO PROJETO DO NOVO CÓDIGO ELEITORAL SOBRE O FINANCIAMENTO PARTIDÁRIO E ELEITORAL NO BRASIL
}

\section{Denise Goulart Schlickmann ${ }^{1}$}

\section{RESUMO}

O projeto do novo Código Eleitoral ${ }^{2}$ que tramita no Congresso Nacional impacta grandemente o sistema de financiamento partidário e eleitoral no Brasil. Ao tempo em que reestrutura o financiamento partidário e traz alterações pontuais no financiamento eleitoral, revela fragilidades nos instrumentos de controle, deixando entrever que uma de suas principais consequências é a limitação de atuação da Justiça Eleitoral, que vê muito reduzidas as suas competências de exame de regularidade do financiamento dos partidos políticos no Brasil.

Palavras-chave: Partidos Políticos. Eleições. Financiamento partidário. Financiamento de campanhas eleitorais. Reforma eleitoral. Código Eleitoral.

\section{THE NEW ELECTORAL CODE PROJECT'S IMPACT ON PARTY AND ELECTORAL FINANCING IN BRAZIL}

\begin{abstract}
The draft of the new Electoral Code that is being discussed in the National Congress has a great impact on the party and electoral financing system in Brazil. At the same time that it restructures party financing and brings specific changes in electoral financing, it reveals weaknesses in the control instruments, revealing that one of its main consequences is the limitation of the Electoral Court's performance, which sees its competences to examine the regularity of the financing of political parties in Brazil very reduced.
\end{abstract}

Keywords: Political parties. Elections. Party funding. Election campaign financing. Electoral reform. Electoral Code.

\section{INTRODUÇÃO}

\footnotetext{
${ }^{1}$ Doutoranda no Programa de Pós-Graduação em Direito da Universidade Federal de Santa Catarina. Mestra em Direito pela UFSC. Bacharel em Ciências Econômicas, Ciências Contábeis e Direito, pela Universidade Federal de Santa Catarina (UFSC). Pós-graduada em Auditoria Governamental pela FEPESE/UFSC, e em Direito Eleitoral pela UNIVALI. Membro do Núcleo de Inteligência da Justiça Eleitoral. Secretária de Controle Interno e Auditoria do TRE/SC. Conferencista na área de direito eleitoral. Autora da obra Financiamento de Campanhas Eleitorais, na décima edição, pela Editora Juruá. Coautora da obra Tratado de Direito Eleitoral, pela Editora Fórum. Coautora da obra Tópicos Avançados de Direito Processual Eleitoral, pela Editora Arraes. Coautora da obra Dicionário das Eleições, pela Editora Juruá. Organizadora e coautora da obra Questões Eleitorais Contemporâneas: uma análise por servidores da Justiça Eleitoral, pela Editora Plácido. Contato: deniseschlickmann@gmail.com.

${ }^{2}$ Até o momento em que se produz este estudo não contém número de protocolo.
} 
De há muito o ordenamento jurídico eleitoral reclama sistematização de suas normas. Apenas para exemplificar, dentre os diplomas mais significativos que moldam a legislação eleitoral, o Código Eleitoral (Lei n ${ }^{\circ}$ 4.737/1965), datado de 1965, encontra-se praticamente revogado em sua grande maioria; por sua vez, a Lei dos Partidos Políticos (Lei no 9.096/1995) e a Lei das Eleições (Lei $n^{\circ}$ 9.504/1997) foram submetidas a tantas reformas (praticamente uma reforma eleitoral a cada dois anos) que acabaram por constituir-se em verdadeiras colchas de retalhos, com inúmeros defeitos técnicos e dispositivos conflitantes. A Justiça Eleitoral, por sua vez, regulamentando as eleições, consolidou procedimentos operacionais que não se encontram previstos na legislação eleitoral, mas que tornam efetivamente viáveis a realização das eleições e buscam conferir a sistematização necessária ao conjunto de normas legais vigentes e por vezes contraditórias. Não há dúvidas, pois, de que a aprovação de um novo Código Eleitoral é necessária e extremamente bem-vinda.

Contudo, considerando-se a magnitude da obra, é necessário identificar pontos que possam merecer a rediscussão e aperfeiçoamento e este é o objetivo deste estudo: alinhar em tópicos específicos, referenciando os dispositivos do projeto, o que se considera impactante para o financiamento partidário e eleitoral brasileiros.

\section{FINANCIAMENTO PARTIDÁRIO}

Preliminarmente, é importante destacar que o projeto contempla, separadamente, o disciplinamento do financiamento partidário e eleitoral, inclusive no que se refere à prestação de contas, deixando de contemplar a necessária uniformidade de tratamento ao financiamento político, o que por vezes dificulta a atuação dos partidos políticos - sujeitos a regulamentações diferentes quando se trata do financiamento partidário ou eleitoral.

Feita esta consideração inicial, são os seguintes os pontos cruciais que denotam grande impacto sobre o financiamento partidário no Brasil:

1. Fontes vedadas - disparidade com as fontes vedadas eleitorais

Art. 59. É vedado a partido político receber, direta ou indiretamente, sob qualquer forma ou pretexto, contribuição ou auxílio pecuniário ou estimável em dinheiro, inclusive através de publicidade de qualquer espécie, procedente de:

I - entidade ou governo estrangeiro; 
II - entes públicos e pessoas jurídicas de qualquer natureza, ressalvadas as dotações provenientes do Fundo Partidário e do FEFC;

III - pessoa física que exerça atividade comercial decorrente de permissão; ou

IV - autoridades públicas.

$\S 1^{\circ}$ Consideram-se autoridades públicas, para fins do inciso IV do caput, pessoas físicas que exerçam função ou cargo público de livre nomeação e exoneração, ou cargo ou emprego público temporário, ressalvados os filiados a partido político.

O regime de fontes vedadas, ao tempo em que não se equipara às vedações do financiamento eleitoral, dispostas no art. 425 do projeto $^{3}$, tem como ponto mais crítico a manutenção da redação que define o conceito de autoridades do inciso IV.

O conceito, ao referir expressamente a exclusão dos filiados a partido político do conceito de autoridade, retira a eficácia do próprio dispositivo, eis que a probabilidade de que tais doações provenham justamente de pessoas vinculadas ao partido político beneficiário é por demais evidente.

2. Balanço contábil

Art. 60. Ressalvadas as vedações estabelecidas neste Código, o partido político pode receber doações de pessoas físicas para as hipóteses previstas no art. 57.

$\S 1^{\circ}$ As doações de que trata este artigo podem ser feitas diretamente aos órgãos de direção nacional, estadual, distrital, zonal e municipal, que deverão expressamente registrar seu recebimento, identificação do doador e respectiva destinação, inclusive balanço contábil, obrigando-se a informar aos órgãos de instância partidária superior, assim como fazê-lo constar na prestação de contas. (grifou-se)

Em seu art. 60, $\S 1^{\circ}$, o projeto mantém a referência à expressão "balanço contábil", que tecnicamente não corresponde a nenhuma demonstração contábil ou financeira vigente,

\footnotetext{
${ }^{3}$ Observe-se, em relação às fontes vedadas eleitorais, que de forma despicienda especifica inúmeras pessoas jurídicas de direito eleitoral, quando o inciso III expressamente veda o financiamento eleitoral por pessoa jurídica de direito privado.
} 
deixando obscuro a que peça contábil se refere, o que pode ser referência à mera contabilização de informações e não a instrumento contábil específico.

3. Admissão de depósitos em espécie

Art. $60[\ldots] \$ 2^{\circ}$ As doações de recursos financeiros somente poderão ser efetuadas na conta do partido político por meio de:

II - depósitos em espécie devidamente identificados; (grifou-se)

$\mathrm{O}$ memo artigo, em seu $\S 2^{\circ}$, prevê expressamente a possibilidade de recebimento de recursos em espécie. A modalidade, permitindo o depósito integral da doação em espécie com identificação do depósito, acaba por permitir que o depositante seja identificado e não a verdadeira fonte de financiamento, não sendo raras as vezes com que a Justiça Eleitoral se depara com essa situação (v.g. o depositante, mero intermediário, figura indevidamente como doador, o que se constata apenas quando da aferição de cumprimento de limites de doação realizada pela Receita Federal, que constata a incompatibilidade da renda com a doação efetuada).

Ademais, a restrição ao uso de recursos em espécie no Brasil é, inclusive, objeto de ações específicas da ENCCLA (Estratégia Nacional de Combate à Corrupção e à Lavagem de Dinheiro), razão pela qual a legislação eleitoral deve prever não a permissão, mas a vedação de ingresso de recursos em campanha por essa modalidade.

4. Assunção de obrigações por esferas partidárias sem restrição da espécie de recurso utilizada para quitação de dívidas

Art. 63. Órgãos partidários de qualquer esfera podem assumir obrigação de outro órgão, mediante acordo, expressamente formalizado, que deve conter a origem e o valor da obrigação assumida, os dados e a anuência do credor.

Em oposição à regra de assunção de obrigações por esferas partidárias disposta para o financiamento eleitoral no projeto, a regra que vigora para o financiamento partidário prevê no art. 63 - sem quaisquer restrições quanto à fonte de pagamento - que uma esfera partidária possa assumir obrigação de outra. A regra vigente, não preservada no projeto, proíbe que na hipótese de assunção de obrigações partidárias a quitação ocorra com recursos do Fundo Partidário sempre que o órgão que transfere a dívida esteja proibido de receber essa espécie de 
recursos. A medida resguarda a eventual burla à aplicação da sanção pelo seu recebimento indireto pela via do pagamento de dívidas do partido sancionado com essa espécie de recursos.

5. Previsão de recebimento de doações de pessoas jurídicas para composição do Fundo Partidário

Art. 64. O Fundo Especial de Assistência Financeira aos Partidos Políticos (Fundo Partidário) é constituído por:

I - multas e penalidades pecuniárias aplicadas nos termos deste Código Eleitoral e leis conexas;

II - recursos financeiros que lhe forem destinados por lei, em caráter permanente ou eventual;

III - doações de pessoa física ou jurídica, efetuadas por intermédio de depósitos bancários diretamente na conta do Fundo Partidário; (grifou-se)

O projeto prevê como fonte vedada o financiamento partidário por pessoas jurídicas, mas permite que o financiamento empresarial ocorra na composição do Fundo Partidário, o que culmina por financiar indiretamente os partidos políticos com essa fonte vedada de arrecadação, eis que o Fundo Partidário é atualmente uma de suas principais fontes de financiamento.

Ressalte-se, por fim, que não há limites fixados para tais doações, ou seja, podem representar valores muito significativos para o financiamento partidário, os quais, por sua vez, podem alcançar o financiamento eleitoral, já que o Fundo Partidário pode ser aplicado em campanhas eleitorais.

6. Inserção de hipótese de utilização de recursos do Fundo Partidário em desacordo com a previsão de realização de gastos dessa natureza

Art. 68. Os recursos oriundos do Fundo Partidário serão aplicados:

I - na manutenção das sedes e serviços do partido, permitido o pagamento de pessoal, a qualquer título, observado, do total recebido, os seguintes limites:

a) $50 \%$ (cinquenta por cento) para o órgão nacional;

b) $60 \%$ (sessenta por cento) para cada órgão estadual e

municipal; 


$$
\begin{aligned}
& \text { II - na propaganda doutrinária e política; } \\
& \text { III - no alistamento e campanhas eleitorais; } \\
& \text { IV - na criação e manutenção de instituto ou fundação de }
\end{aligned}
$$
pesquisa e de doutrinação e educação política, sendo esta aplicação de, no mínimo, vinte por cento do total recebido.

V - na criação e manutenção de programas de promoção e difusão da participação política das mulheres, criados e executados pela Secretaria da Mulher ou, a critério da agremiação, por instituto com personalidade jurídica própria presidido pela Secretária da Mulher, em nível nacional, conforme percentual que será fixado pelo órgão nacional de direção partidária, observado o mínimo de 5\% (cinco por cento) do total;

VI - no pagamento de mensalidades, anuidades e congêneres devidos a organismos partidários internacionais que se destinem ao apoio à pesquisa, ao estudo e à doutrinação política, aos quais seja o partido político regularmente filiado;

VII - no pagamento de despesas com alimentação, incluindo restaurantes e lanchonetes;

\section{VIII - no pagamento de despesas com transporte} aéreo, incluindo a compra de bilhetes e a locação de aeronaves, desde que vinculado às atividades partidárias;

IX - na contratação de serviços de consultoria contábil e advocatícia e de serviços para atuação jurisdicional em ações de controle de constitucionalidade e em demais processos judiciais e administrativos de interesse partidário, bem como nos litígios que envolvam candidatos do partido, eleitos ou não, relacionados exclusivamente ao processo eleitoral;

$\mathrm{X}$ - na compra ou locação de bens móveis e imóveis, bem como na edificação ou construção de sedes e afins, e na realização de reformas e outras adaptações nesses bens;

XI - no custeio de impulsionamento, para conteúdos contratados diretamente com provedor de aplicação de internet com sede e foro no País, incluída a priorização paga de conteúdos resultantes de aplicações de busca na internet, mediante o pagamento por meio de boleto bancário, de depósito identificado ou de transferência eletrônica diretamente para conta do provedor, o qual deve manter conta bancária específica para 
receber recursos dessa natureza, proibido nos 180 (cento e oitenta) dias anteriores à eleição. (grifou-se)

A matéria encontra-se repetida no art. $61, \S 1^{\circ}$, que não contém a nova hipótese de aplicação dos recursos do Fundo Partidário quando trata especificamente dos gastos partidários custeado com essa espécie de recursos.

7. Manutenção da ampliação artificial dos limites de gastos com pessoal realizados com Fundo Partidário

Art. 68 [...] $§ 4^{\circ}$ Não se incluem no cômputo do percentual previsto no inciso I deste artigo encargos e tributos de qualquer natureza.

Os gastos com pessoal realizados com Fundo Partidário estão limitados percentualmente a $50 \%$ para o órgão nacional e a $60 \%$ para os órgãos estadual ou municipal. A exclusão desse cômputo dos encargos e tributos relativos a essas despesas fere tanto a natureza de tais gastos quanto as normas contábeis aplicáveis à sua identificação, produzindo o efeito de elevar artificialmente a natureza desses gastos.

8. Manutenção de regra que permite o desvio de finalidade nos recursos destinados à fundação partidária

Art. $68[\ldots] \S 6^{\circ}$ No exercício financeiro em que a fundação ou instituto de pesquisa não despender a totalidade dos recursos que lhe forem assinalados, a eventual sobra poderá ser revertida para outras atividades partidárias, conforme previstas no caput deste artigo. (grifou-se)

Os recursos do Fundo Partidário podem ser aplicados exclusivamente nas hipóteses dispostas na legislação eleitoral. Uma delas prevê (art. 68, IV) a aplicação mínima do percentual de $20 \%$ na criação e manutenção de instituto ou fundação de pesquisa e de doutrinação e educação política.

A previsão de que os recursos não utilizados na fundação partidária que lhe forem destinados por força da disposição legal dentro do exercício possam ser utilizados em quaisquer outras atividades partidárias culmina por retirar a eficácia do dispositivo. A inércia na aplicação desses recursos, por si só, é suficiente à sua destinação diversa daquela que foi originariamente concebida pelo legislador.

9. Manutenção da regra que permite o ressarcimento de despesas partidárias 
Art. 69. [...] Parágrafo único. O partido político poderá ressarcir despesas comprovadamente realizadas no desempenho de atividades partidárias e deverá manter registro contábil de todos os dispêndios efetuados, sem computar esses valores para os fins do inciso I do caput do art. 44 desta Lei.

A permissão de ressarcimento de despesas constante do dispositivo autoriza o pagamento indireto a fornecedores, o que retira da Justiça Eleitoral a possibilidade de cruzamento direto de dados com o sistema financeiro nacional. Referido cruzamento confere precisão à aferição da destinação dos recursos, possibilitando a avaliação exata tanto da caracterização do gasto como partidário, quanto da possibilidade de sua realização, quando pago com recursos do Fundo Partidário, para os quais o mesmo projeto de lei restringe a aplicação.

10. Concentração da matéria de prestação de contas em sua vertente contábil, em detrimento do cumprimento de obrigações de natureza eleitoral

Art. 70. O partido político, através de seus órgãos nacionais, regionais e municipais que tiverem arrecadação e gastos, deverá manter escrituração contábil mediante o Sistema Público de Escrituração Digital da Receita Federal (SPED), de forma a permitir o conhecimento da origem de suas receitas e a destinação de suas despesas, e encaminhar o respectivo relatório à Justiça Eleitoral para análise.

De há muito a Justiça Eleitoral não mais detém a competência para fiscalizar contabilmente os partidos políticos. Isso porque - como Justiça Especializada - a Justiça Eleitoral concentra o seu exame de regularidade de contas no cumprimento das obrigações de natureza eminentemente eleitoral.

Ademais, a Justiça Eleitoral não conta em seus quadros com técnicos contábeis aptos ao exame contábil de contas a que se destinaria o SPED, especialmente no primeiro grau de jurisdição, que concentra a maciça maioria de contas prestadas, relativas aos diretórios municipais de partidos políticos.

Ora, como pessoas jurídicas de direito privado, incumbe aos partidos políticos manter escrituração contábil de sua movimentação, nos termos a que estão sujeitas todas as demais pessoas jurídicas, sofrendo regulação e fiscalização específica nesse aspecto.

À Justiça Eleitoral o acesso ao SPED é mero subsídio para aferição do cumprimento das obrigações de natureza eleitoral, para o que a simples contabilização não é suficiente. 
11. Restrição de competência à Justiça Eleitoral para o exame de regularidade de contas partidárias - atribuição a empresas terceirizadas de auditoria a função de aferição de contas e retirada do caráter judicial dos processos de contas partidárias

Art. 71. É facultado aos órgãos partidários, de qualquer esfera, contratar instituições privadas de auditoria e conformidade previamente cadastradas perante a Justiça Eleitoral para acompanhar e fiscalizar a execução financeira anual sob a responsabilidade do partido político.

$\S^{\circ}$ Na hipótese prevista neste artigo, a prestação de contas do órgão do partido político, a ser apresentada à Justiça Eleitoral, será acompanhada do número de protocolo da escrituração contábil no Sistema Público de Escrituração Digital da Receita Federal (SPED) do exercício findo, bem como de relatório elaborado pela instituição auditora e de conformidade que reflita incongruências nos dispêndios realizados e, se for o caso, nos recursos aplicados em campanhas eleitorais.

$\$ 2^{\circ}$ A Justiça Eleitoral deverá cadastrar previamente empresas especializadas na prestação dos serviços de auditoria e de conformidade para os fins do parágrafo único deste artigo.

$\S^{\circ}$ O processo de prestação de contas dos órgãos partidários que optarem pela contratação de instituição privada especializada em auditoria e conformidade terá natureza administrativa e será submetido a julgamento pela Justiça Eleitoral, assegurada ampla defesa, somente podendo ser desaprovadas na hipótese de o relatório de auditoria apresentar incongruências na movimentação financeira da agremiação.

\$4 $4^{\circ}$ É admitida a participação da instituição privada especializada em auditoria e conformidade contratada pelo partido político nos processos de prestação de contas, na qualidade de assistente técnico da respectiva agremiação, garantindo-lhe as prerrogativas previstas no art. 466, do CPC.

$\S 5^{\circ}$ Sem prejuízo da atuação prevista no $§ 3^{\circ}$, a Justiça Eleitoral poderá solicitar informações relacionadas à execução 
financeira sob a responsabilidade do partido político contratante durante o exercício financeiro em curso.

$\$^{\circ}$ Em caso de desaprovação das contas dos diretórios partidários que optarem pela modalidade de prestação de contas prevista neste artigo, aplica-se sanção de multa, no patamar de $\mathbf{R} \$ 5.000,00$ (cinco mil) a $\mathbf{R} \$ 30.000,00$ (trinta mil) reais, devendo a Justiça Eleitoral, quando da sua aplicação, observar os princípios da proporcionalidade e da razoabilidade, sem prejuízo da devolução da importância apontada como irregular.

$\S 7^{\circ}$ A sanção a que se refere o $§ 6^{\circ}$, será descontada das quotas dos Fundo Partidário a que faz jus o órgão do partido político, de forma parcelada. (grifou-se)

Uma das disposições mais danosas ao processo eleitoral constantes do projeto é, sem dúvida alguma, a extrema restrição de competência à Justiça Eleitoral para fiscalizar e manifestar-se pela regularidade de contas partidárias, no que se pode apontar como praticamente uma terceirização do exame de contas, ao encargo de empresas privadas, blindando-se os partidos políticos da atuação direta da fiscalização da Justiça Eleitoral.

O projeto prevê que os partidos políticos possam contratar instituições privadas de auditoria com essa específica finalidade - de fiscalização da sua atuação financeira. Nessa hipótese, à guisa de prestação de contas, no lugar de receber in natura as informações de receitas e gastos partidárias para exame, a Justiça Eleitoral receberia mero relatório produzido por tais empresas de auditoria, acompanhados do protocolo de sua escrituração contábil.

À Justiça Eleitoral incumbiria - ironicamente - a função de cadastrar tais empresas (que lhe fariam as vezes na matéria que até então é de sua competência da fiscalização e pronunciamento sobre a regularidade de contas partidárias).

Mais não fosse - não fosse suficientemente danosa a blindagem privada dos partidos políticos - tais processos de contas perderiam a natureza judicial para tornarem-se administrativos, o que retira completamente a possibilidade de atribuição de sanções definitivas, uma vez que jamais transitariam em julgado, possibilitando um eterno fazer e refazer de contas.

E se ainda a regulamentação não fosse prejudicial à transparência do exame de regularidade de contas, o projeto impõe à Justiça Eleitoral que só possa desaprovar contas quando o relatório de auditoria - contratado pelo próprio prestador de contas - "não 
refletir a real movimentação financeira da agremiação", circunstância que dificilmente se alcançaria, já que a competência de fiscalização de contas já não estaria com a Justiça Eleitoral para que pudesse chegar a tal conclusão.

E quando - e se - tal condição de desaprovação se concretizasse, multa irrisória variando de $\mathrm{R} \$ 5.000,00$ a $\mathrm{R} \$ 30.000,00$ seria imposta, o que, considerando-se o porte de um grande diretório partidário nacional representaria pouco mais do que nada. Mantém-se a regra de devolução da importância apontada como regular, mas o próprio termo "devolução" não raras vezes induz à percepção de que se aplica apenas a recursos públicos recebidos. Ainda assim, a encerrar com chave de ouro a proposição, a irrisória sanção seria quitada pela via do desconto de quotas do Fundo Partidário a receber. Claro, de forma parcelada.

Descaracteriza-se, pois, tanto a natureza, quanto a forma e, principalmente, a efetividade do instituto de prestação de contas, justamente aquele aos quais estão submetidas as instituições permanentes que sustentam o regime democrático, os partidos políticos, que em muitas circunstâncias, notadamente nos âmbitos nacional e municipal, movimentam vultosas somas de recursos.

12. Limitação de competência no exame de regularidade pela Justiça Eleitoral restrição de escopo e retirada do caráter judicial dos processos que julgam contas

Art. 72. Em procedimento administrativo, a Justiça Eleitoral deverá apurar nas prestações de contas:

I - existência de receitas de fontes vedadas ou de origem não identificada;

II - o correto valor no repasse das cotas destinadas às respectivas Fundações e no percentual do fundo partidário de aplicação vinculada, nos termos deste Código;

Não bastasse a desarrazoada terceirização de exame de contas examinada no item 11, uma vez mais o projeto reduz ao extremo o escopo de análise que incumbiria à Justiça Eleitoral sobre a regularidade de contas, limitando indevidamente sua atuação quanto a dois aspectos específicos: a identificação de fontes vedadas e recursos de origem não identificada e à correção do repasse de recursos às fundações partidárias (cuja distorção já se examinou no item 8) e aos demais repasses vinculados. 
Ora, até para que seja eficaz, a competência para fiscalizar deve ser ampla e irrestrita, desde que observado o devido processo legal, justamente para assegurar-se que todas as regras dispostas na legislação eleitoral foram devidamente observadas.

Por fim, o dispositivo fixa uma vez mais o conceito de processo administrativo, em evidente retrocesso à evolução do caráter judicial que confere estabilidade às decisões proferidas pela Justiça Eleitoral, principalmente no que se refere à aplicação de sanções. Considerando-se que os partidos políticos - ao contrário dos candidatos - possuem natureza permanente, seguindo-se ao exercício financeiro a que se referem as contas imediatamente exercício seguinte, a execução de sanções torna-se praticamente inviável no escopo administrativo dos processos, cujas decisões não transitam em julgado e que precisam afetar os exercícios seguintes dos quais o partido político prestará contas nos anos subsequentes.

De anotar-se a singularidade de que a perda do caráter judicial aos processos de prestação de contas prevista no código não se estende às prestações de contas de campanha eleitoral e que é justamente no processo de contas partidário que se concentram os maiores volumes de recursos submetidos a julgamento.

13. Previsão de mera obrigação de envio à Justiça Eleitoral de declaração de ausência de movimentação de recursos, em qualquer nível, em oposição à obrigação constitucional de prestar contas

Art. 73 [...] Os órgãos partidários de qualquer instância que não tenham movimentado recursos financeiros ou arrecadado bens estimáveis em dinheiro devem encaminhar ao respectivo juízo eleitoral declaração da ausência de movimentação de recursos nesse período e estarão desobrigados de enviar declarações de isenção, declarações de débitos e créditos tributários federais ou demonstrativos contábeis à Receita Federal do Brasil, bem como ficam dispensados da certificação digital. (grifou-se)

A obrigação de prestar contas é pressuposto constitucional de existência dos partidos políticos disposta no art. 17 da Constituição Federal, que dispõe:

Art. 17. É livre a criação, fusão, incorporação e extinção de partidos políticos, resguardados a soberania nacional, o regime democrático, o pluripartidarismo, os direitos fundamentais da pessoa humana e observados os seguintes preceitos:

I - caráter nacional; 
II - proibição de recebimento de recursos financeiros de entidade ou governo estrangeiros ou de subordinação a estes;

\section{III - prestação de contas à Justiça Eleitoral;}

IV - funcionamento parlamentar de acordo com a lei.

(grifou-se)

Justamente em razão da impossibilidade de, na via ordinária, derrogar-se o comando constitucional, eventual declaração de ausência de prestação de contas é recebida como prestação de contas sem movimentação financeira, sujeita a rito específico de instrução, uma vez que a nenhuma das esferas partidárias permite-se o descumprimento do dever de prestar contas, o que a redação mantida induz a crer.

14. Previsão de reativação de CNPJ com data retroativa

Art. $73[\ldots] \S 5^{\circ} \mathrm{O}$ requerimento a que se refere o $\S 4^{\circ}$ deste artigo indicará se a agremiação partidária pretende a efetivação imediata da reativação da inscrição pela Secretaria Especial da Receita Federal do Brasil ou a partir de $1^{\circ}$ de janeiro de 2020, hipótese em que a efetivação será realizada sem a cobrança de quaisquer taxas, multas ou outros encargos administrativos relativos à ausência de prestação de contas.

O projeto prevê a reativação de CNPJs de partidos inativados retroativamente, falha que decorre da mera manutenção de dispositivo aprovado na Lei 13.831/2019.

\section{FINANCIAMENTO ELEITORAL}

Ao examinar-se os dispositivos que se referem ao financiamento eleitoral, ao contrário do financiamento partidário, vê-se que há uma incorporação significativa das regras emanadas do Tribunal Superior Eleitoral na Resolução TSE nº 23.607/2019.

As propostas de alteração são mais pontuais - ou seja, não são estruturantes - mas exercem também impacto relevante sobre o financiamento eleitoral. Senão vejamos:

1. Desobrigação de abertura de conta bancária para o recebimento de doações de campanha para diretórios municipais

Art. 400. A conta bancária Doações para Campanha, prevista no inciso III do art. 410 deve ser aberta em agências bancárias ou postos de atendimento bancário: 
I - pelo candidato, no prazo de 10 (dez) dias contados da concessão do CNPJ de campanha e;

II - pelos partidos políticos, no prazo de 10 (dez) dias do registro no Tribunal Superior Eleitoral, no caso de diretório nacional, e da respectiva anotação partidária, no caso de diretório regional, possuindo referida conta caráter permanente.

O projeto prevê a obrigação de abertura de conta bancária para o recebimento de doações de campanha, de caráter permanente, apenas para diretórios nacionais e estaduais, eximindo os diretórios municipais dessa obrigação, que deve ser prevista também considerando-se o prazo de sua respectiva anotação no TRE (procedimento equivalente ao registro observado para as esferas estadual e municipal).

Caso não haja obrigação de abertura de conta para esses diretórios, frustra-se a providência preliminar a conferir legalidade ao recebimento de doações, as quais são atos voluntários e imprevisíveis, possibilitando-se o eventual trânsito paralelo de recursos na ocorrência de doações dessa espécie.

2. Desobrigação, pelos bancos, de identificar fornecedores de campanha nos extratos bancários.

Art. 401. Os bancos são obrigados a:

I - acatar, em até 3 (três) dias, o pedido de abertura de conta de qualquer partido político ou de candidato escolhido em convenção, ainda que vencidos os prazos fixados neste Código, sendo-lhes vedado condicionar a conta ao depósito mínimo e à cobrança de taxas ou de outras despesas de manutenção;

\section{II - identificar, nos extratos bancários o CPF ou o}

\section{CNPJ do doador;}

III - encerrar as contas bancárias dos candidatos destinadas à movimentação de recursos do Fundo Partidário e de doações para campanha no fim do ano da eleição, transferindo a totalidade do saldo existente para a conta bancária do órgão de direção da circunscrição e informar o fato à Justiça Eleitoral;

IV - encerrar as contas bancárias do candidato e do partido político destinadas à movimentação de recursos do Fundo Especial de Financiamento de Campanha (FEFC) no fim do ano da eleição, 
transferindo a totalidade do saldo existente para o Tesouro Nacional e informar o fato à Justiça Eleitoral. (grifou-se)

A redação proposta deixa de prever a obrigatoriedade de identificação dos fornecedores de campanha nos extratos bancários eletrônicos encaminhados à Justiça Eleitoral.

A precisa identificação de fornecedores é elemento essencial não apenas à transparência das contas eleitorais como à precisa identificação dos gastos realizados, permitindo a aferição de se os recursos eleitorais foram destinados diretamente aos fornecedores. Assim, sua identificação perante o sistema financeiro nacional é de extrema importância.

3. Ausência de identificação de candidatos e partidos políticos pelo CNPJ nos extratos bancários

Art. $401[\ldots] \S 1^{\circ}$ Os bancos somente aceitarão, nas contas abertas para uso em campanha, depósitos ou créditos de origem identificada pelo nome do doador e pelo respectivo número de inscrição no CPF.

O projeto deixa de prever a obrigatoriedade de identificação de CNPJ de doadores, possivelmente considerando que a identificação de CNPJs refere-se exclusivamente a doações de pessoas jurídicas, vedada pelo projeto.

Contudo, candidatos e partidos políticos são fontes lícitas de arrecadação de recursos e estão identificados pelo número de inscrição no CNPJ, única forma de identificação precisa desses doadores perante o sistema financeiro nacional.

4. Simplificação do financiamento de campanhas eleitorais mediante empréstimos, com a exclusão de requisitos importantes à aferição cabal das fontes de financiamento

Art. 406 [...] Parágrafo único. A utilização de recursos que tenham sido obtidos mediante empréstimo somente é admitida quando a contratação ocorrer em instituições financeiras ou equiparadas autorizadas a funcionar pelo Banco Central do Brasil e, no caso de candidatos, quando não ultrapassem a capacidade de pagamento decorrente dos rendimentos de sua atividade econômica.

As regras que atualmente vigoram nas normas emanadas do Tribunal Superior Eleitoral para a utilização de empréstimos em campanhas eleitorais - em tese incorporadas no projeto - buscam garantir a idoneidade dos empréstimos e a identificação precisa das fontes financiadores da campanha. 
Os critérios normativos vigentes primam por estabelecer requisitos hábeis a contratações idôneas (exigindo que sejam garantidos por bens integrantes do patrimônio do candidato antes do registro de sua candidatura; que não ultrapassem a capacidade de pagamento do beneficiário e que sejam contratados ante instituições oficiais); identificar com precisão as fontes de financiamento (exigindo a quitação dos valores utilizados na campanha pois, se assim não fosse, o pagamento posterior ao julgamento das contas poderia ser realizado com fontes não submetidas ao crivo de legalidade, possibilitando que fossem ilícitas); permitir que a autoridade judicial exija a identificação da origem dos recursos utilizados para quitação, sob pena de considera-los de origem não identificada.

O projeto restringe tais critérios a apenas dois: a contratação junto a instituições oficiais e a comprovação da capacidade de pagamento, afrouxando controles sobre importante fonte financiadora que ingressa em campanhas eleitorais como recursos próprios.

5. Manutenção do estabelecimento dos critérios para distribuição do FEFC a candidatos pela cúpula partidária

Art. $408[\ldots] \$ 3^{\circ}$ Os recursos de que trata este artigo ficarão à disposição do partido político somente após a definição de critérios para a sua distribuição, os quais devem ser estabelecidos de forma objetiva pelo respectivo órgão colegiado nacional e amplamente divulgados em todas as suas instâncias. (grifou-se)

O projeto mantém a competência exclusiva do órgão diretório nacional para definição dos critérios de distribuição dos recursos do Fundo Especial de Financiamento de Campanha entre candidatos.

A concentração do poder decisório na cúpula partidária tende a perpetuar as esferas de poder intrapartidárias, revelando prática que vai de encontro à necessária democracia dentro das esferas partidárias que possibilitaria maior participação na definição do destino dos recursos públicos. Prejudica, ainda, a necessária transparência na definição de critérios.

A mera designação de que incumbe ao diretório nacional decidir sobre a distribuição dos recursos retira da grande maioria dos candidatos a possibilidade de acesso ao fundo para financiar sua campanha.

A regra não fixa parâmetros objetivos para a distribuição dos recursos, sequer estabelece critérios de equidade na sua distribuição, sendo possível, a partir da regra proposta - e que já vigora na legislação eleitoral - a concentração absoluta de recursos. 
A estratégia partidária concentra-se - no que se refere ao financiamento de campanhas com recursos do FEFC - unicamente no diretório nacional.

A distribuição dos recursos do fundo condicionada exclusivamente à definição, pelo próprio partido político - esfera nacional - dos critérios a serem adotados para a sua distribuição, ainda que aprovados pela maioria absoluta dos membros da executiva nacional e divulgados publicamente, possibilita que os recursos públicos, cujo fundo instituído prevê tenham finalidade de financiar campanhas eleitorais, possam ser direcionados também de forma exclusiva. A ausência total de critérios legais de distribuição de recursos revela potencial de desvio de finalidade e destoa das disposições legais que impõem critérios de utilização para os recursos públicos.

6. Inexistência de procedimentos legais para distribuição dos recursos do Fundo Especial de Financiamento de Campanha a candidatos

Art. $409[\ldots] \S 1^{\circ}$ Para que o candidato tenha acesso aos recursos do Fundo a que se refere este artigo, deverá fazer requerimento por escrito ao órgão partidário respectivo.

No mesmo viés do dispositivo anterior, o projeto fixa apenas a necessidade de que o candidato apresente requerimento para obter tais recursos. Não disciplina a respeito da sua efetiva entrega, suprimindo todo o procedimento de estabelecimento de critérios objetivos para distribuição dos valores recebidos pelo partido político.

7. Configuração da vedação de recursos de fonte estrangeira (entidade ou governo estrangeiro) em detrimento da origem estrangeira dos recursos

Art. 425. É vedado a partido político e a candidato receber, direta ou indiretamente, doação em dinheiro ou estimável em dinheiro, inclusive por meio de publicidade de qualquer espécie, procedente de:

$$
\text { I - entidade ou governo estrangeiro; [...] }
$$

As normas em vigor, sedimentadas pelo Tribunal Superior Eleitoral, preveem que a configuração da fonte vedada não depende da nacionalidade do doador, mas da procedência dos recursos doados.

A regra não foi incorporada no projeto e, dessa forma, a vedação passa a estar caracterizada apenas quando o doador - entidade ou governo - seja estrangeiro. 
Assim, permite-se que o recurso de origem estrangeira possa financiar campanhas eleitorais brasileiras, bastando que para isso chegue às campanhas por intermédio de pessoas física nacional, o que subverte a intenção da norma, que é a de não permitir o financiamento internacional às campanhas eleitorais brasileiras.

8. Manutenção da exclusão dos gastos efetuados com advogados e contadores dos limites de gastos e de doações estimáveis em dinheiro

Art. $4209[\ldots] \S 14^{\circ} \mathrm{O}$ pagamento efetuado por pessoas físicas e candidatos em decorrência de honorários advocatícios e de contabilidade, relacionados à prestação de serviços em campanhas eleitorais e em favor destas, bem como em processo judicial decorrente de defesa de interesses de candidato ou partido político, não será considerado para aferição do limite de pessoa física previsto no caput do art. 428 e seu $\S 1^{\circ}$, não está sujeito aos limites de gastos de campanha e também não constitui doação de bens e serviços estimáveis em dinheiro.

O dispositivo opera duas exclusões importantes para as normativas de financiamento de campanha eleitoral, no que se refere às despesas realizadas com advogados e contadores. A primeira delas refere-se à exclusão do limite de gastos, elevando artificialmente o limite de gastos legalmente fixados pela ausência de cômputo de gasto eleitoral relevante às campanhas eleitorais. A segunda refere-se à exclusão dessas mesmas despesas do conceito de doação estimável em dinheiro, o que permite a realização desses gastos por terceiros sem que sejam computados na prestação de contas de campanha, afetando substancialmente a transparência desses gastos e, por conseguinte, da íntegra do financiamento de campanha.

9. Permissão para a realização de doações de bens e serviços estimáveis em dinheiro para candidatos não integrantes da coligação partidária

Art. 432. O candidato ao cargo majoritário e os partidos que compõem a respectiva coligação podem realizar gastos em favor dos candidatos proporcionais e dos partidos integrantes da coligação majoritária.

Com o fim das coligações para as eleições proporcionais, configura-se a ausência de interesse jurídico na eleição de candidato a essa espécie de eleição pertencente a outro partido político. Isso porque o interesse jurídico na eleição concretiza-se com a formação da coligação, hoje permitida apenas para a eleição majoritária.

Assim, permitir a realização de gastos por integrantes de coligação majoritária em favor dos candidatos proporcionais significa permitir doações estimáveis em dinheiro a esses, 
em evidente desvio de finalidade dos recursos recebidos, cuja composição passa a ser cada vez mais predominante por recursos públicos.

10. Atribuição ao TSE para fixação de limite de gastos

Art. 434. O limite de gastos de campanha, em cada eleição, são os definidos pelo Tribunal Superior Eleitoral, com base em parâmetros não inferiores aos utilizados nas eleições gerais e municipais imediatamente anteriores.

Parágrafo único. Nas campanhas para segundo turno das eleições para prefeito, onde houver, o limite de gastos de cada candidato será de $40 \%$ (quarenta por cento) do limite previsto no caput deste artigo. (grifouse)

O projeto atribui ao Tribunal Superior Eleitoral a competência para fixar os limites de gastos de cada eleição sem estabelecer nenhum critério a ser observado salvo o da não inferioridade àqueles estabelecidos na eleição anterior.

Perde-se a oportunidade de contemplar critérios técnicos para fixação de limites na própria legislação eleitoral, de que são exemplos o custo das eleições, o eleitorado a atingir e eventuais peculiaridades locais.

11. Gastos de simpatizantes - manutenção da exclusão dos gastos com advogados e contadores dos limites fixados

Art. 438 Com a finalidade de apoiar candidato de sua preferência, qualquer eleitor pode realizar gastos até o valor, inclusive, de $\mathrm{R} \$ 2.000,00$ (dois mil reais), não sujeitos à contabilização, desde que não reembolsados.

$\S 1^{\circ} \mathrm{Na}$ hipótese prevista neste artigo, o comprovante da despesa deve ser emitido em nome do eleitor.

$\S 2^{\circ}$ Fica excluído do limite previsto no caput deste artigo o pagamento de honorários decorrentes de prestação de serviços advocatícios e de contabilidade, relacionados às campanhas eleitorais $\mathrm{e}$ em favor destas. (grifou-se)

A menção legislativa não se amolda ao próprio conceito de gasto de simpatizante, que contém em si a compreensão de que são gastos independentes cujo produto não é entregue ao candidato, consoante a farta jurisprudência da Justiça Eleitoral. 
Gastos com advogados e contadores jamais poderiam ser realizados à margem da campanha, sem afetá-la diretamente como serviços entregues ao candidato e, portanto, ser assim configurados como gastos de simpatizantes, instituto que serve à realização de despesas de pequena monta independentes e desvinculadas da campanha, na maciça maioria das vezes sem sequer o conhecimento do candidato beneficiado. A manutenção da regra fere a publicidade e a transparência dos gastos realizados com advogados e contadores.

12. Restrição à transparência e ao controle social nos relatórios financeiros de campanha

Art. 463. Os partidos políticos e os candidatos são obrigados, durante as campanhas eleitorais, a enviar à Justiça Eleitoral, por meio do SPCE, para divulgação em página criada na internet para esse fim, relatório financeiro de doações, de caráter meramente informativo, discriminando:

I - as transferências do Fundo Partidário e do Fundo Especial de Financiamento de Campanha (FEFC);

II - os recursos financeiros recebidos.

$\S 1^{\circ}$ As informações sobre os recursos recebidos a que se refere o caput deverão ser informadas à Justiça Eleitoral em até 72 (setenta e duas) horas, contadas a partir do recebimento, considerando a data do efetivo crédito na conta bancária de campanha.

§2 ${ }^{\circ}$ A intempestividade de apresentação das informações previstas no caput, se corrigida em tempo hábil, configura irregularidade de natureza meramente formal e não enseja na desaprovação das contas.

$\S^{\circ}$ A omissão de informação no caput, quando corrigida na apresentação da prestação de contas final ou em retificadora, poderá levar a ressalvas, caso devidamente justificadas, ou à desaprovação, se dotada de gravidade e analisada em conjunto com outras irregularidades de natureza grave.

$\S^{\circ}$ As informações sobre gastos contratados e doações estimáveis recebidas somente deverão ser enviadas na prestação de contas final. (grifou-se)

O projeto ao tempo em que minimiza a importância de informar à Justiça Eleitoral tempestivamente sobre o financiamento da campanha eleitoral, viabilizando o controle 
concomitante de contas e o controle social, restringe a íntegra das informações então prestadas apenas aos recursos financeiros recebidos.

Ficam excluídos os gastos eleitorais realizados e as doações em bens e serviços, limitando injustificadamente o acesso pleno à integra do financiamento das campanhas eleitorais durante a sua realização.

A publicidade de dados é corolário da transparência material das contas, que viabiliza inclusive importantes ações de inteligência hoje executadas pelo Núcleo de Inteligência da Justiça Eleitoral, mediante o cruzamento dos dados da campanha com bases de dados oficiais de importantes órgãos de fiscalização. De relembrar-se que são as ações de inteligência que possibilitam identificar o uso fraudulento de CPFs e CNPJs, bem como a ausência de capacidade econômica para financiar campanhas ou de capacidade operacional para fornecer bens e serviços em campanhas eleitorais, expedientes que não raras vezes indicam à identificação irreal de doadores e fornecedores de campanha.

13. Restrição de acesso às notas fiscais eletrônicas relativas ao fornecimento de bens e serviços para candidatos

Art. 481. A Secretaria da Receita Federal do Brasil e as secretarias estaduais e municipais de Fazenda encaminharão ao Tribunal Superior Eleitoral, pela internet, arquivo eletrônico contendo as notas fiscais eletrônicas relativas ao fornecimento de bens e serviços para partidos políticos. (grifou-se)

O projeto prevê que as fazendas públicas remetam as bases de dados de notas fiscais eletrônicas exclusivamente relativas aos partidos políticos, excluindo a parcela mais significativa de dados e crucial ao exame das contas de campanha eleitoral, que são justamente aquelas relacionadas aos próprios candidatos.

É muito expressivo o avanço técnico de fiscalização de contas após a disponibilização, pelas fazendas públicas, de suas bases de dados de notas fiscais eletrônicas, viabilizando o confronto com os gastos declarados nas prestações de contas.

Impossibilitando-se o acesso a esses dados restringe-se a aferição da efetiva realização de gastos em confronto com as informações constantes dos processos de prestação de contas, revelando retrocesso extremamente danoso à transparência e exame de regularidade de contas de campanha eleitoral no país. 


\section{CONCLUSÃO}

O projeto do novo Código Eleitoral que tramita no Congresso Nacional, no que se refere ao financiamento eleitoral e partidário, em primeiro exame, revela características extremamente importantes. Ainda que o projeto pretenda incorporar normas procedimentais já há muito estabilizadas na Justiça Eleitoral, certo é que traz alterações muito significativas que tendem a reduzir de forma extrema as competências da Justiça Eleitoral, reduzindo, de igual sorte, importantes instrumentos de controle de regularidade e transparência desse que é um dos pilares do regime democrático: o financiamento da política.

Em suma, à guisa de conclusão, revela-se nos pontos destacados sensível prejuízo à transparência, ao controle social e ao controle de regularidade sobre as contas. Não se olvide, a propósito, que o controle de regularidade sobre as contas precisa ser exercido de forma ampla pela Justiça Eleitoral, para ser legítimo, observados notadamente dois princípios basilares do Estado Democrático Brasileiro: o devido processo legal e a separação dos poderes da República, respeitando-se as instituições às quais a Constituição Federal atribuiu competência para a prestação jurisdicional.

\section{REFERÊNCIAS}

BRASIL, Lei no 4.737, de 15 de julho de 1965. Código Eleitoral. Diário Oficial da União, Brasília, DF, 19 jul 1965. Seção 1, p. 6746.

Lei $\mathrm{n}^{\circ}$ 9.504, de 30 de setembro de 1997. Estabelece normas para as eleições.

Diário Oficial da República Federativa do Brasil, Brasília, DF, 1 out. 1997. Seção 1, p. 21.801 .

Lei $\mathrm{n}^{\circ}$ 9.096, de 19.09.1995. Dispõe sobre partidos políticos, regulamenta os artigos 17 e 14, $\S 3^{\circ}$, inciso V, da Constituição Federal. Diário Oficial da República Federativa do Brasil, Brasília, DF, 20 set 1995. Seção 1, p. 14.552.

. Tribunal Superior Eleitoral. Resolução no 23.607, de 17 de dezembro de 2019.

Dispõe sobre a arrecadação e os gastos de recursos por partidos políticos e candidatos e sobre a prestação de contas nas eleições. DJE-TSE n. 249, Brasília, DF, 27 dez 2019, p. 125-156 